\title{
The physical and chemical properties of solid waste from water tourism. Case study: Taling Chan Floating Market, Bangkok, Thailand
}

\author{
S. R. Tuprakay ${ }^{1}$, P. Suksabye ${ }^{1}$, P. Menchai ${ }^{1} \&$ S. Tuprakay ${ }^{2}$ \\ ${ }^{I}$ Faculty of Science and Technology, \\ Suan Dusit Rajabhat University, Thailand \\ ${ }^{2}$ Faculty of Engineering, Ramkhamhaeng University, Thailand
}

\begin{abstract}
Solid waste management represents one of the most challenging and perpetual issues for many developing countries in the world, especially regarding solid waste in important areas such as floating markets. Water tourism is at an ever rapid rate of growth and generates a lot of income into Thailand. The aim of this research is to investigate the physical and chemical properties of solid waste produced by water tourism in Taling Chan Floating Market, Thailand. The results showed five types of waste; food, plastics, paper, leaves and foam. The largest component of all was food waste, which accounted for $53.95 \%$ of total waste. Solid waste density was measured at $0.55 \mathrm{~kg} / \mathrm{m} 3$ and the size of solid waste varied from $0.3-20 \mathrm{~cm}$ in width and $3-49 \mathrm{~cm}$ in length. The moisture content, combustion compound, ash, content of carbon, levels of hydrogen, sulphur, nitrogen and oxygen accounted for $65.76 \%, 82.0 \%, 6.17 \%, 45.56 \%$, $5.03 \%, 0.1268 \%, 4.95 \%$, and $44.24 \%$, respectively. The calorific value of the waste was not high, measured at $4,170.46 \mathrm{cal} / \mathrm{g}$, which included a low level of hydrogen content of $5.12 \%$. Therefore, the solid waste from Taling Chan Floating Market was not suitable for combustive fuel due to its high moisture content. Regarding the level of heavy metal detection, it was found that $\mathrm{As}, \mathrm{Cd}$, $\mathrm{Cr}, \mathrm{Cu}, \mathrm{Hg}$, and $\mathrm{Pb}$ were $2.490 \mathrm{ppb}, 0.127 \mathrm{ppb}, 18.853 \mathrm{ppb}, 0.175 \mathrm{ppb}, 5.103 \mathrm{ppb}$ and $34.762 \mathrm{ppb}$, respectively. The levels of heavy metal detection here were still in the range of the Thailand soil quality standard. The heavy metal and nitrogen contents also showed potential for use as fertilizer or organic fertilizer. The
\end{abstract}


knowledge of this research is essential in estimating the suitable methods for the management of Taling Chan Floating Market's solid waste.

Keywords: solid waste, physical characterization, chemical characterization, water tourism, floating market.

\section{Introduction}

Currently, water tourism is at an ever rapid rate of growth and generates a lot of income into Thailand. This means it also generates employment and distribution of income to the local community. Thailand has a high potential for water tourism as there are plenty of natural attractions such as rivers and streams. The government have urged to promote tourism within the community, especially water activities such as the "Floating Market", using the focus of a unique national culture to attract Thai and overseas tourists, i.e. selling local products, local cruises and home stay accommodation for visitors [1]. Also, the provision of cultural performances for tourists could stimulate economy and generate income for the community.

Taling Chan Floating Market in Bangkok (Fig. 1) is a tourist attraction that was founded in 1987 to promote tourism in Bangkok. Open on a Saturday and Sunday of each week, it is situated in the heart of the capital but still remains the folk way of local lives. Farmers in the area harvest the food products from their gardens or locally growing plants, including fresh fruit, vegetables and fish to earn their living. These products will always have rotation among the seasons. In addition, restaurants on the waterfront provide a variety of food and desserts, together with the selling of craft products made from local wisdom . Taling Chan Floating Market is now famous and has started to be recognized by many tourists. As such, the cultural environment and natural balance of the area has been destroyed. A statistic from Taling Chan District Office declared 170 vendors and 600 tourists a day.

Solid waste management represents one of the most challenging and perpetual issues for many developing countries in the world. The management of urban solid wastes in developing countries is far from positive and the elimination of this waste remains one of the main challenges to the authorities. The causes for this are as follows: firstly, rural emigration, with regards to the management of waste, affects the housing environment, education, health and the environment, secondly, the domain of the setting-up of the population most decreases when it is not mastered by the persons in charge and thirdly, the sectors of valuation of urban solid residues are not yet mastered. The brulage, wild garbage dumps and raw discharge constitute the final release in conditions which do not necessarily meet the necessary guarantees to avoid atmospheric pollution, the contamination of ground waters and grounds and the harming of the environment [2]. Solid waste management is a challenge for city authorities in developing countries mainly due to the increasing generation of waste, the burden posed on the municipal budget as a result of the high costs associated to its management, the lack of understanding over a diversity of factors that affect the different stages of waste management and the linkages necessary to enable the entire handling 
system functioning [3]. Many previous studies have examined household solid waste (HSW) generation and physical waste composition. Berneche-Perez et al. [4], Ojeda-Benitez et al. [5], Alhumoud et al. [6], and Gómez et al. [7] analyzed HSW to identify the waste generation rate and the potential for using recyclable wastes. However, the HSW generation rates and compositions were found to differ among communities. Some studies describe correlations between household solid waste quantities and characteristics and relevant socioeconomic factors [8-13].

This research aims to study the physical and chemical properties of solid waste within Taling Chan Floating Market. Waste stream characteristics must be understood to tackle waste management in Taling Chan Floating Market, Thailand. The knowledge of solid waste composition is essential in estimating methods for its elimination as composting material, the recycling of metals and other recyclable materials.
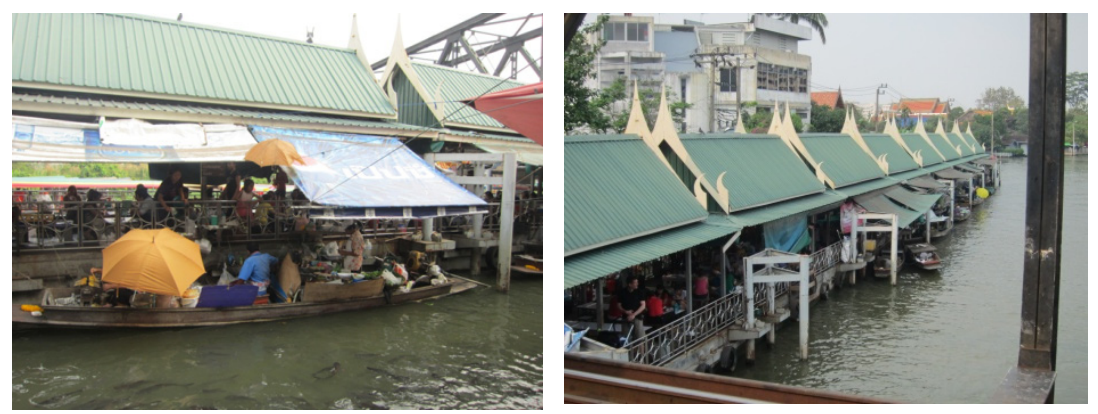

Figure 1: Taling Chan Floating Market in Bangkok, Thailand.

\section{Methodology}

\subsection{Physical properties}

The physical properties of solid waste, comprised of composition, size and density are explored as follows.

\subsubsection{Composition}

The composition of Taling Chan Floating Markets' solid waste mass can be determined by the percentage of waste fractions. It involves the weighing of individual components of the volume of solid waste in selected samples and this determines their percentage. The waste is then sorted out into 5 categories: food waste, plastic, paper, leaves and foam.

\subsubsection{Size}

The size of Taling Chan Floating Markets' solid waste is represented in the centimeter unit of width and length for each waste composition. 


\subsubsection{Density}

Density is defined as the weight of a material per unit volume. It can be calculated by

$$
D=\frac{W_{1}-W_{2}}{V}
$$

where

$\mathrm{D}=$ Density

$\mathrm{W}_{1}=$ Weight of fresh waste and waste measured container

$\mathrm{W}_{2}=$ Weight of waste measured container

$\mathrm{V}=$ Volume of waster measured container

\subsection{Chemical properties}

The chemical properties of solid waste are composed of moisture content, volatile solid, ash content, CHNSO contents, calorific value and heavy metal.

\subsubsection{Moisture content}

The moisture content of each material was measured through weight difference at $75^{\circ} \mathrm{C}$ till a constant weight was acquired (USDA and USCC, 2002, [14]). The dried material was then ground using a solid waste cutting mill (RETSCH, Model SM 100) equipped with a $1.5 \mathrm{~mm}$ mesh screen, and was homogenized for elemental analysis and calorific value quantification.

\subsubsection{Volatile solid content}

The volatile solid in dry material was determined according to the methods ASTM D 5832-96. Volatile matter exhibited an additional loss of weight on ignition at $950^{\circ} \mathrm{C}$ in a covered crucible.

\subsubsection{Ash content}

Ash content in dry material was determined according to the methods ASTM D 2866-96. Ash content exhibited a weight of residue after combustion in an open crucible.

\subsubsection{Carbon (C), hydrogen (H), nitrogen (N), sulphur (S), and oxygen (O) content}

The $\mathrm{C}, \mathrm{H}, \mathrm{N}, \mathrm{S}$ and $\mathrm{O}$ contents were measured via an elemental analyzer (CE Instruments, CHNS-O Model EA-1110, Thermo Electron) according to the following procedure: $1-6 \mathrm{mg}$ of the dried and ground samples were placed in tin capsules during the $\mathrm{C}, \mathrm{N}, \mathrm{H}, \mathrm{S}$ analyses and in silver capsules during $\mathrm{O}$ analysis. $\mathrm{C}, \mathrm{N}, \mathrm{H}$ and $\mathrm{S}$ were measured concurrently upon the insertion of one sample. Electrolytic copper and copper oxide were used as the catalysts during $\mathrm{C}, \mathrm{N}, \mathrm{H}, \mathrm{S}$ analyses and the reaction chamber temperature was kept at $1000^{\circ} \mathrm{C}$. Helium flow was maintained at $120 \mathrm{ml} / \mathrm{min}$ and oxygen injection lasted $60 \mathrm{~s}$. The purity of $\mathrm{O}_{2}$ used during the quantification of $\mathrm{C}, \mathrm{N}, \mathrm{H}$ and $\mathrm{S}$ was $99.9 \%$.

\subsubsection{Calorific value}

The calorific value or energy content of solid waste was determined by using a laboratory bomb calorimeter. Firstly, the energy content was measured on a wet 
basis of waste using $1 \mathrm{~g}$ randomly selected samples according to the ASTM E-711 using a state-of-the-art oxygen bomb calorimeter Model ASMI 711 provided with digital computer control and display capabilities.

\subsubsection{Heavy metal content}

Heavy metal contents are composed of Arsenic (As), Cadmium (Cd), Cromium (Cr), Copper $(\mathrm{Cu})$, Mercury $(\mathrm{Hg})$ and Lead $(\mathrm{P})$ using the Inductive Coupled Plasma Spectroscopy (ICP) Jobin Yvon model JY 124.

\subsection{Sampling venue}

Samples were taken from the solid waste tank within Taling Chan Floating Market, Bangkok, Thailand (Fig. 2).

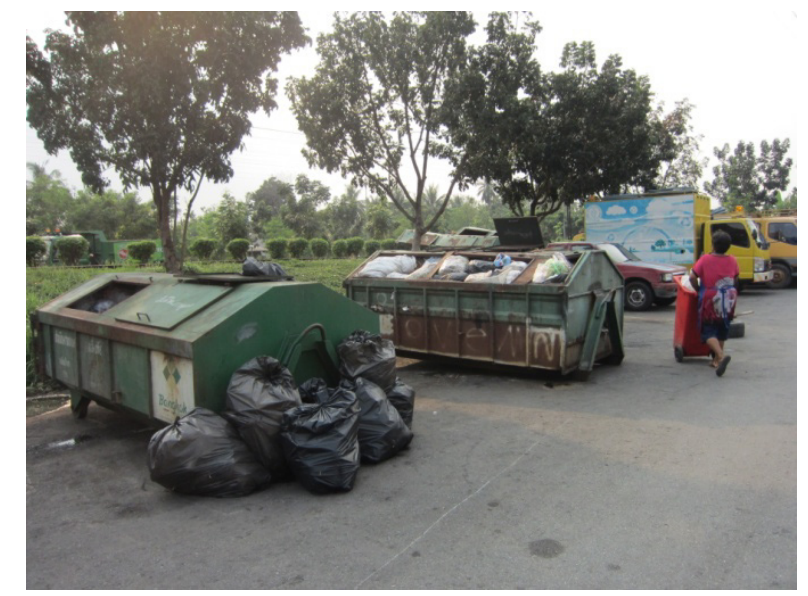

Figure 2: $\quad$ Solid waste tank within Taling Chan Floating Market.

\section{Results}

\subsection{Physical properties}

\subsubsection{Composition of solid waste}

There were 5 categories of solid waste composition. The composition analysis revealed a composition of $53.95 \%$ food waste, $14.55 \%$ plastic, $12.20 \%$ paper, $11.04 \%$ leaves and $8.26 \%$ foam. The dominant composition here was food waste, which accounted for $53.95 \%$ of the total composition and is due to the selling of food and beverages within the floating market. The runners-up were plastics, leaves and foam, respectively. Table 1 shows the percentages of composition within the range of $8.26-14.55 \%$, which were consistent with activities within the floating market. Therefore, food waste was found to exist within this range the most out of all the types. This result showed that the solid waste composition of the floating market was different from the solid waste composition of the city 
according to the works of Naïma et al. [2]. Although, the characterization of solid waste in the cities of low-income countries in Asia, especially South Asian countries, is unique in composition and in its solid waste generation rate. The solid waste stream is characterized with a large organic fraction of approximately $70 \%$ [15], included in the work of Thanh et al. [13]. In Can Tho city, the capital city of the Mekong Delta region in southern Vietnam the compostable and recyclable shares respectively account for $80.02 \%$ and $11.73 \%$.

Table 1: The composition percentages in Taling Chan Floating Market.

\begin{tabular}{l|c|c}
\hline \hline Composition & $\begin{array}{c}\text { Percent of composition } \\
(\mathbf{\%})\end{array}$ & $\begin{array}{c}\text { Weight of composition } \\
(\mathbf{g})\end{array}$ \\
\hline 1.Food waste & 53.95 & 1,000 \\
\hline 2.Plastic & 14.55 & 1,200 \\
\hline 3.Paper & 12.20 & 680 \\
\hline 4.Leaves & 11.04 & 4,440 \\
\hline 5.Foam & 8.26 & 912 \\
\hline Total & $\mathbf{1 0 0 . 0 0}$ & $\mathbf{8 , 2 3 2}$ \\
\hline \hline
\end{tabular}

\subsubsection{Size of solid waste}

Sorting by size informs us about the proportions of the grading fraction. It was found that the sizes of solid waste were in the range $0-0.3 \mathrm{f} 20 \mathrm{~cm}$ in width and $3-49 \mathrm{~cm}$ in length as shown in Table 2.

Looking at table 2, it can be explained that the size of solid waste influences its collection and transportation. However, both issues have no significant bearing on the length and width in relation to the waste collective tank.

Table 2: The size of solid waste in Taling Chan Floating Market.

\begin{tabular}{c|c|c}
\hline \hline Composition & Width $(\mathbf{c m})$ & Length $(\mathbf{c m})$ \\
\hline 1. Food waste & $1.5-7.5$ & $3-17.5$ \\
2. Plastic & $0.7-1.4$ & $3-23$ \\
\hline 3. Paper & $14-17$ & $17-32$ \\
\hline 4. Leaves & $0.3-20$ & $6-49$ \\
\hline 5. Foam & $11-17$ & $15-25$ \\
\hline \hline
\end{tabular}

\subsubsection{Density}

This research tells us that the density of the solid waste was $0.55 \mathrm{~kg} / \mathrm{m}^{3}$, which affects the transportation of waste to the disposal sites in that it may take up the space of the waste container during the transportation. When compared with the research carried out by Somthip [16] on the capacity and density analysis during the transportation process, it was found that the density of solid waste from the fresh market was $154 \mathrm{~kg} / \mathrm{m}^{\prime}$ comprising of vegetable rubbish, food and organic waste. Therefore, the density of the solid waste was high compared to those from 
Taling Chan Floating Market. In contrast, the density of the solid waste generated from Taling Chang Floating Market consisted of foam, plastic, paper and leaves, which had a low density, considering half of the cited paper.

\subsection{Chemical properties}

The chemical properties comprised of moisture content, volatile solid, ash content and content of carbon, hydrogen, oxygen, nitrogen, sulphur and calorific value as shown in Table 3

The results reveal that the moisture content was in the range of $65.72-65.80 \%$ and at an average of $65.76 \%$ due to the average composition of solid waste, which mostly comprised of organic food that contains a high level of moisture. Volatile solid (combustible substances) of the solid waste in the Taling Chan Floating Market were in the range of $80.55-83.32 \%$ and at an average of $82.00 \%$. The ash content was in the range of 5.72-6.67 and at an average of $45.56 \%$

The calorific value heating value of waste is in the range of $3789.7-4568.7 \mathrm{cal} / \mathrm{g}$ and has an average value of $4170.467 \mathrm{cal} / \mathrm{g}$. Knowledge of the calorific value of MSW is necessary when designing MSW incinerators for energy recovery purposes [17].

Table 3: Chemical properties of solid waste in Taling Chan Floating Market.

\begin{tabular}{l|c|c}
\hline \hline \multicolumn{1}{c|}{ Parameter } & Max-Min & Mean \\
\hline Moisture Content (\%) & $65.72-65.80$ & 65.76 \\
Volatile Solid (\%) & $80.55-83.32$ & 82.00 \\
Ash Content (\%) & $5.72-6.67$ & 6.17 \\
Carbon (\%) & $46.29-44.75$ & 45.56 \\
Hydrogen (\%) & $5.03-5.21$ & 5.12 \\
Sulfer (\%) & $0.1112-0.1495$ & 0.1268 \\
Nitrogen (\%) & $4.80-5.11$ & 4.95 \\
Oxygen (\%) & 44.24 & 44.24 \\
Calorific Value (cal/g) & $3789.7-4568.7$ & 4170.467 \\
\hline \hline
\end{tabular}

\subsection{Content of heavy metal}

The content of heavy metal within Taling Chan Floating Market are shown in Table 4 . The averages of heavy metal in the solid waste from the market were 2.4902, 0.1273, 18.8530, 0.1758, 5.1031 and $34.7622 \mathrm{ppb}$ for arsenic, cadmium, chromium, copper, mercury and lead, respectively. These values meet Thailand's soil quality standard. From the heavy metal content of these solid wastes, it is evident that there is potential to use this waste as the media for a fertilizer. Looking at Table 3, the amounts of nitrogen are shown to be in the range of 4.80 to $5.11 \%$, the average was $4.95 \%$, hence, it is possible to use the waste to produce manure. 
Table 4: Content of heavy metal in solid waste.

\begin{tabular}{lcr}
\hline \hline Parameter & Max-Min & \multicolumn{1}{c}{ Mean } \\
\hline $\mathrm{As}(\mathrm{ppb})$ & $2.4353-2.7588$ & 2.4902 \\
$\mathrm{Cd}(\mathrm{ppb})$ & 0.1273 & 0.1273 \\
$\mathrm{Cr}(\mathrm{ppb})$ & $17.6556-20.0468$ & 18.8530 \\
$\mathrm{Cu}(\mathrm{mgL} /)$ & $0.1753-0.1784$ & 0.1758 \\
$\mathrm{Hg}(\mathrm{ppb})$ & $2.2971-4.5071$ & 5.1031 \\
$\mathrm{~Pb}(\mathrm{ppb})$ & $34.5462-34.9948$ & 34.7622 \\
\hline \hline
\end{tabular}

\section{Conclusion}

This research has produced the first estimates of the physical and chemical properties of solid waste in the Taling Chan Floating Market. On the basis of this survey, the physical characteristics of solid waste in the Taling Chan Floating Market were predominantly comprised of food waste, at $53.95 \%$. The density of the solid waste was $0.55 \mathrm{~kg} / \mathrm{m}^{3}$. The size of the solid waste ranged from $0.3-20$ $\mathrm{cm}$ in width and 3-49 $\mathrm{cm}$ in length. The chemical characteristics of the solid waste demonstrated a low potential to be used as fuel because of its high moisture content. The heavy metal and nitrogen contents showed potential for use as the medium for fertilizer or organic fertilizer. Knowledge of this research is essential for estimating the methods of solid waste elimination through composting, the recycling of metals and of other recyclable materials.

\section{Acknowledgement}

This work was funded by the National Research Council of Thailand and Suan Dusit Rajabhat University, Thailand.

\section{References}

[1] Taling Chang District Office (2011) http://www.bangkok.go.th/talingchan/

[2] Naïma, T. D., Guy, M. C., Serge \& Djamel, T., Composition of Municipal Solid Waste (MSW) generated by the city of Chlef (Algeria), Energy Procedia, 18, pp.762-771, 2012.

[3] Guerrero, L. A., Maas, G. \& Hogland, W., Solid waste management challenges for cities in developing countries, Waste Management, 33 (1), pp. 220-232, 2013.

[4] Berneche-Perez, G., Sanchez-Colon, S., Garmendia, A. M., DavilaVillarreal, A. \& Sanchez-Salazar, M. E., Solid waste characterization study in the Guadalajara metropolitan zone, Mexico, Waste Manage. Res., 19, pp. 413-424, 2001.

[5] Ojeda-Benitez, S., Armijo de Vega, C. \& Ramírez-Barreto, M. E., Characterization and quantification of household solid wastes in a Mexican city, Resour. Conserv. Recycl., 39, pp. 211-222, 2003. 
[6] Alhumoud, J. M., Altawash, M. \& Aljallal, L., Survey and evaluation of household solid waste generation and compositions in Kuwait, Int. J. Environ. Health, 1(4), pp. 517-527, 2007.

[7] Gómez, G., Meneses, M., Ballinas, L. \& Castells, F., Characterization of urban solid waste in Chihuahua, Mexico, Waste Manage, 28, pp. 2465-2471, 2008.

[8] Dennison, G. J., Dodd, V. A. \& Whelan, B., A socioeconomic based survey of household waste characteristics in the city of Dublin, Ireland - I. Waste composition, Resour. Conserv. Recycl, 17, pp. 227-244, 1996a.

[9] Dennison, G. J., Dodd, V. A. \& Whelan, B., A socioeconomic based survey of household waste characteristics in the city of Dublin, Ireland II. Waste quantities, Resour. Conserv. Recycl, 17, pp 245-257, 1996 b.

[10] Bandara, N. J. G. J., Hettiaratchi, J. P. A., Wirasinghe, S. C. \& Pilapiiya, S., Relation of waste generation and composition to socioeconomic factors: a case study, Environ. Monit. Assess., 135, pp. 31-39, 2007.

[11] Sujauddin, M. S., S. Huda, M. S.\& Rafiqul Hoque, A. T. M., Household solid waste characteristics and management in Chittagong, Bangladesh, Waste Manage., 28(9), pp. 1688-1695, 2008.

[12] Qu, X., Li, Z., Xie, X., Sui, Y., Yang, L. \& Chen, Y., Survey of composition and generation rate of household wastes in Beijing, China, Waste Manage., 29(10), pp. 2618-2624, 2009.

[13] Thanh, N. P., Matsui, Y. \& Fujiwara, T., Household solid waste generation and characteristic in a Mekong Delta city Vietnam, Journal of Environmental Management, 91, pp. 2307-2321, 2010.

[14] US Department of Agriculture (USDA) \& US Composting Council (USCC), Test Methods for the Examination of Composting and Compost, in: Thomson, W. (ed.), The Composting Council Research \& Education Foundation, Holbrook, New York, pp. 03.09.1-03.09, 2002.

[15] Forouhar, A. K. \& Hristovski, D., Characterization of the municipal solid waste stream in Kabul, Afghanistan, Habitat International, 36 (3), pp. 406-413, 2012.

[16] Somthip Dantheeravanich, Kasetsart University, www.ku.ac.th.

[17] Komilis, D., Evangelou, A., Giannakis, G. \& Lymperis, C., Revisiting the elemental composition and the calorific value of the organic fraction of municipal solid wastes, Waste Management, 32, pp. 372-381, 2012. 